\title{
FEATURES OF THE DEVELOPMENT OF MEANS FOR SPACECRAFT REMOVAL FROM NEAR-EARTH OPERATIONAL ORBITS
}

\author{
Institute of Technical Mechanics \\ of the National Academy of Sciences of Ukraine and the State Space Agency of Ukraine, \\ 15 Leshko-Popel St., Dnipro 49005,Ukraine; e-mail: Ernando@i.ua
}

A search for optimal solutions in the development and making of means for spacecraft removal from nearEarth operational orbits is the key problem in the solution of the global problem of space debris in near-Earth space. Taking into account the trend to the build-up of space debris in near-Earth orbits, the Inter-Agency Space Debris Coordination Committee every year takes a number of measures aimed at searching for the most advantageous engineering solutions on the development of efficient means for space debris removal from operational orbits. This paper analyzes the features of the development of optimal means for spacecraft removal from nearEarth operational orbits. The main efficiency criteria in the development of optimal methods and means for spacecraft deorbit are as follows: minimizing the space debris deorbit time, increasing the reliability of space debris deorbit means, and minimizing the propellant and power consumption for space debris removal.

Taking into account the above optimization criteria, the paper presents a comprehensive analysis of existing methods and means for space debris removal from low-Earth orbits and shows their anticipated advantages and drawbacks. Three basic tasks of missions aimed at space debris removal from near-Earth space are identified. A fourth task of space debris removal from near-Earth space, which has resulted from the evolving new concept of in-orbit space debris processing with the use of in-orbit service spacecraft and platforms, is identified and substantiated too. A multicriteria comprehensive comparative analysis of the best known concepts of the development and making of means for space debris removal from near-Earth orbits is presented. The features of the development of combined space debris deorbit means based on several existing methods for active and passive space debris removal from low-Earth orbits are considered. The principal aim of the development of combined hybrid space debris deorbit means of this type is a search for engineering solutions that would meet the above-mentioned efficiency criteria as closely as possible.

The comprehensive multicriteria analysis of the currently available means for space debris removal from low-Earth orbits and the features of the development of hybrid space debris deorbit means demonstrates the advisability of further studies along this line.

Keynords space debris deorbit means, near-Earth operational orbit, optimization criteria.

1. Space Debris. In 2 books, Book 1. Observation Methods and Space Debris Models (in Russian). Prof. G. G. Raykunov (Ed.). Moscow: FIZMATLIT, 2014. 245 pp.

2. Space Debris. In 2 books, Book 1. Space Debris Prevention (in Russian). Prof. G. G. Raykunov (Ed.). Moscow: FIZMATLIT, 2014. 188 pp.

3. Kessler D. J., Johnson N. L., Liou J.-C., Matney M. The Kessler syndrome: implications to future space operations. 33-rd Annual AAS Guidance and Control Conference. Breckenridge, Colorado. February $6-10,2010$. URL: http://citeseerx.ist.psu.edu/viewdoc/download?doi=10.1.1.394.6767\&rep=rep1\&type=pdf (date of access April 22, 2019)

4. The Orbital Debris Quarterly News. NASA JSC Houston. 2019. Iss 1\&2. Vol. 23. P. 14.

5. Alpatov A. P., Goldstein Yu. M. Ballistic analysis of orbits distribution of spacecraft for different functional missions (in Russian). Teh Meh. 2017. No. 2. Pp. 33-40.

6. Lovell T.A., Tragesser S. Guidance for relative motion of low earth orbit spacecraft based on relative orbit elements. AIAA Paper 2004-4988, presented at the AAS/AIAA Astrodynamics Specialist Conference, Providence, RI. 2004.

7. Khramov D. A. Miniaturized satellites of Cubesat standard. Kosm. Nauka Tehnol (in Russian). 2009, V. 3 No.15 Pp. 20-31. doi: 10.15407/knit2009.03.020

8. Paliy A. S. Methods and means of removing spacecraft from working orbits (state of the problem). Teh. Meh. (in Russian). 2012. No. 1. Pp. 94-102.

9. Alpatov A. P. Space debris: the aspects of the problem (in Russian). Teh. Meh. 2018. No. 1. Pp. 30-47.

10. Alpatov A. P.(Ed.), Bass V. P., Baulin S. A., Brazinskii V. I., Gusynin V. P., Daniev Yu. F., Zasukha S. A. The Development and Creation of Space Technology. Technogenic Clogging of Near-Earth Space (in Russian). - Dnipropetrovsk: Porogi, 2012. 378 pp.

11. Alpatov, A. P., Maslova, A. I., Khoroshilov, S. V. Contactless Removal of Space Debris by the Ion Beam. Dynamics and Control. Beau Bassin: LAP Lambert Academic Publishing, 2018. 331 pp.

12. Pikalov R. S., Yudincev V. V. Review and selection of means of deorbiting of large space debris (in Russian). Trydu MAI. 2018. No. 100. URL: http://trudymai.ru/upload/iblock/239/Pikalov_YUdintsev_rus .pdf?lang=ru\&issue $=100$ (date of access April 22, 2019). 
13. Golovko M. G., Bezugly V. A., Bondarenko S. G., Rubakha Y. A., Pokrovskiy R. O. Technical aspects of space refuse control (in Russian). Ecology and Noospherology. 2012. V. 23, No. 1-2. Pp. 110-120. doi: http://www.uenj.cv.ua/Noo_2012_Vol-23_No1-2/Golovko.pdf

14. Paliy A. S., Skorik A. D. Analysis of use of aerodynamic systems to deorbit modular large-sized space objects from low near-earth orbits (in Russian). Teh. Meh. 2014. No. 2. Pp. 43-51.

15. Alpatov A. P., Paliy A. S., Skorik A. D. Aerodynamic systems for removing space objects (in Russian). Teh. Meh. 2015. No. 4. Pp. 126-138.

16. Lapkhanov E., Paliy A. Analysis of technologies for spacecraft removal from low Earth orbits using onboardproduced electromagnetic and magnetic fields. Teh. Meh. 2018. No. 4. Pp. 21-29.

17. Sergeev V. , Byrdaev . N., Golovko .V. Removal method from a geostationary orbit of a non-functioning spacecraft (in Russian): Patent of Russian Federation 2014115630/11, IPC7, B 64 G 1/00; 25593921 filed April 28, 2014; publ. August 10, 2015.

18. Alpatov . P., Gorbulin V. P. Orbital space platforms for industrial complex: problems and prospects (in Russian). Visn. Nac. Akad. Nauk Ukr. No. 12. Pp. 26-38. doi: 10.15407/visn2013.12.026

19. Alpatov . P. Information models and technologies for combating anthropogenic pollution of near space (in Russian). System Technologies. 2018. Iss. 116. No.3. Pp. 3-14.

20. Christophe Bonnal, Jean-Marc Ruault, Marie-Christine Desjean. Active debris removal: Recent progress and current trends. Acta Austronautica. 2013, V. 85, Pp. 51-60. doi: 10.1016/j.actaastro.2012.11. 009

21. Afanasiev I. Rocsat 2 - high-resolution operational surveyor for Taiwan (in Russian). Novosti Kosmonavtiki. 2004. V. 14. No. 7. Pp. 26-29. URL: http://novosti-kosmonavtiki.ru/mag/2004/1068/ (date of access April 22, 2019).

22. Dudeck M., Doveil F., Arcis N., Zurbach S. Plasma propulsion for geostationary satellites and interplanetary spacecraft. Rom. Journ. Phys. Bucharest, 2011. V. 56. Pp. 3-14. URL: http://www.nipne.ro/rjp/ 2011_56_Suppl/0003_0014.pdf (date of access April 22, 2019).

23. Alby F. SPOT-1 End of life disposal maneuvers. Advances in Space Research. 2004. No. 35. Pp. $1335-1342$. doi: 10.1016/j.asr.2004.12.013

24. Alpatov . P., Belonozhko P. ., Belonozhko P. P., Grigoreev S. V., Tarasov S. V., Fokov . . Modeling the dynamics of space manipulators on a movable base (in Russian). Robototechnika i Technicheskaya Kibernetika. 2013. No. 1. Pp. 61-65.

25. Shan M., Guo J., Gill E. Review and comparison of active space debris capturing and removal methods. Progress in Aerospace Sciences. 2016. V. 80. Pp. 18-32. doi: 10.1016/j.paerosci.2015.11.001

26. Pelton J.N. New Solutions for the Space Debris Problem. Springer. 2015. 94 pp.

27. Xin M., Pan H. Nonlinear optimal control of spacecraft approaching a tumbling target. Aerospace Science and Technology. 2011. V. 15, No. 2. Pp. 79-89. doi: 10.1016/j.ast.2010.05.009

28. Yoshida K., Nakanishi H., Ueno H., Inaba N., Nishimaki T., Oda M. Dynamics, control and impedance matching for robotic capture of a non-cooperative satellite. Advanced Robotics. 2004. V. 18. No. 2. Pp. 175198. doi: 10.1163/156855304322758015

29. Han W., Huang Y., Chen X. Research of impact dynamic modeling of flexible probe-cone docking mechanism based on Kane method. Archive of Applied Mechanics. 2015. V. 85. No. 2. Pp. 205-221. doi: 10.1007/s00419014-0912-4

30. Moody C.K., Probe A.B., Masher A., Woodbury T., Saman M., Davis J., Hurtado J.E. Laboratory experiments for orbital debris removal. In: AAS Guidance, Navigation and Control Conference, Breckenridge, Colorado, USA. 5 - 10 February. 2016. Pp. 1-12.

31. Wormnes K., Le Letty, R., Summerer L., Schonenborg R., Dubois-Matra O., Luraschi E., Delaval J. ESA technologies for space debris remediation. In: 6th European Conference on Space Debris, Darmstadt, Germany. April 22, 2013. V. 1. Pp. 1-8.

32. Benvenuto R., Salvi S., Lavagna M. Dynamics analysis and GNC design of flexible systems for space debris active removal. Acta Astronautica. 2015. V. 110. Pp. 247-265. doi: 10.1016/j.actaastro.2015.01.014

33. Trushlyakov V. I., Yudincev V. V., Makarov Yu. N., Shatrov Ya. . A method for cleaning the orbit from objects of space debris (in Russian): Patent of Russian Federation. 2018105002, IPC7, B64G 1/56, B64G 1/64; RU2676368(13)C1 filed February 9,2018; publ. December 28, 2018.

34. Goff J. A, Judson M. I., Hoyt W., Ryan F. P., Bolton W. G. Sticky boom non-cooperative capture device: Patent of USA. 13/312,984, IPC B25.9/00, B25. 5/02, B25. I5/06, B25. I5/00, B25, 18/00; US 2012.0076629A1 filed December 062011 ; publ. March 292012.

35. Aslanov V. S., Alekseev . V., Ledkov . S. Determination of the parameters of a harpoon-equipped cable system for towing space debris (in Russian). Trudy MAI. 2016. No. 90. URL: http://trudymai.ru/published.php?ID=74644 (date of access April 22, 2019).

36. Dudziak R., Tuttle S., Barraclough S. Harpoon technology development for the active removal of space debris. Advances in Space Research. 2015. V. 56. No. 3. Pp. 509-527. doi: 10.1016/j.asr.2015.04.012

37. Kypreev $S$. . Conditions for the existence of limit cycles for a dynamic system of motion of related objects in an elliptical orbit (in Russian). Trudy MAI. 2016. No. 88. URL: http://trudymai.ru/published. php?ID=69696 (date of access April 22, 2019).

38. Alpatov A., Cichocki F., Fokov A., Khoroshylov S., Merino M., Zakrzhevskii A. Determination of the force trans mitted by an ion thruster plasma plume to an orbital object. Acta Astronautica. 2016. No.119. Pp. 241251. doi: 10.1016/j.actaastro.2015.11.020 
39. Alpatov A. P., Fokov A. A., Khoroshylov S. V., Savchuk A. P. Error analysis of method for calculation of noncontact impact on space debris from ion thruster. Mechanics. Materials Science \& Engineering. 2016. No. 5. Pp. 64-76. doi: 10.13140/RG.2.1.3986.1361

40. Khoroshilov $S$. V. Synthesis of robust controller for ion beam shepherd control system (in Russian). Teh. Meh. 2017. No. 1. Pp. 26-39.

41. Khoroshylov $S$. V. Relative motion control system of spacecraft for contactless space debris removal (in Ukrainian). Nauka Innov. 2018, V. 14 No. 4. Pp. 5-8. doi: 10.15407/scin14.04.005

42. Bombardelli C., Urrutxua H., Merino M., Ahedo E., Peláez. J. Relative dynamics and control of an ion beam shepherd satellite. Spacefl. Mech. 2012. V. 143. Pp. 2145-2158. doi: oai:oa.upm.es:22872

43. Bombardelli C., Pelaez J. Ion beam shepherd for asteroid deflection. Journal of Guidance, Control and Dynamics. 2011. V. 34, No. 4. Pp. 1270-1272. doi: 10.2514/1.51640

44. Maslova, A.I., Pirozhenko, A.V. Orbit changes under the small constant deceleration (in Russian). Space Sci.\&Technol. 2016. V. 6. No 22. Pp. 20-24. doi: 10.15407/knit2016.06.020

45. Paliy . S., Alpatov A. P., Skorik O. D. A method for removing space objects from near-Earth orbits and a system for its implementation (in Ukrainian): Patent of Ukraine. 109318 Ukraine: IPC B 64 G 1/62, No. 109318; 20131326; filed. November 14, 2013; publ. August 10, 2015, Bul. No. 15.11 pp.

46. Paliy . S., Alpatov A. P., Pylypenko .V., Skorik O. D. A method for reducing the ballistic existence of space objects in near-Earth orbits and a spacecraft for its implementation. (in Ukrainian): Patent of Ukraine. 113747 Ukraine: IPC B 64 G 1/62; 201407652; filed. July 07, 2014; publ. March 10, 2017, Bul. No 5. 11 pp.

47. Paliy . S., Alpatov A. P., Skorik O. D., Avdeev. ., Baranov Ye. Yu. Aerodynamic system for removing space objects from near-Earth orbits (in Ukrainian): Patent of Ukraine. 109194, IPC B 64 G 1/62; 201312759; filed November 01, 2013; publ. July 27, 2015, Bul. No. 14. 12 pp.

48. Alpatov A. P., Paliy . S., Skorik $O$. D. The development of structural design and the selection of design parameters of aerodynamic systems for de-orbiting upper-stage rocket launcher (in Ukrainian). Nauka Innov. 2017. V. 13 No. 4. Pp. 33-45. doi: 10.15407/scin13.03.033

49. Nock K. T. Balloon device for lowering space object orbits : Patent of USA. 10/394,477, IPC B64G1/62; No. 6830222; filed May 21 2003, publ. December 14, 2004.

50. Fleeter R., DeBra D. B., Gloyer P., Wahl Z., Goldshtein D. Aerobraking orbit transfer vehicle: Patent of USA 09/925,207, IPC B64G1/22; No. 6550720; filed August 09, 2001, publ. April 22, 2003.

51. Rasse B., Damilano P., Dupuy C. Satellite inflatable deorbiting equipment for LEO spacecrafts. Journal of Space Safety Engineering. 2014. V. 1, No. 2. Pp. 75-83. doi: 1016/S2468-8967(16)30084-2

52. Roddy M., Huang Po-Hao A. Development of a solid-state inflation balloon for aerodynamic drag assisted deorbit of CubeSats. The University of Arkansas, Fayetteville Arkansas, USA. URL: http://www.unisecglobal.org/ddc/pdf/1st/06_MorganRoddy_pre.pdf (date of access April 22, 2019).

53. Bernardi F., Vignali $G$. Sailing system for cubesat deorbiting. University of Rome, Italy. 2016. URL: http://www.unisec-global.org/ddc/pdf/1st/01_FedericoSailing_abst.pdf (date of access April 22, 2019).

54. Andrews J., Watry K., Brown K. Nanosat deorbit and recovery system to enable new missions. 25th Annual AIAA/USU Conference on Small Satellites. URL: https://digital comons.usu.edu/cgi/viewcontent.cgi? article $=1164 \&$ context $=$ smallsat (date of access April 22, 2019).

55. Viquerat A., Schenk M., Sanders B., Lappas V. Inflatable rigidisable mast for end-of-life deorbiting system. ESA. URL: http://www.markschenk.com/research/files/SSMET2014-InflateSail.pdf (date of access April 22, 2019).

56. Alhorn D. C., Casas J. P., Agasid E. F., Adams C. L., Laue G., Kitts C., O'Brien S. The small satellite That Could!. Proceedings of the 25th Annual AIAA/USU Conference on Small Satellites. Logan, 2011. URL : https://ntrs.nasa.gov/archive/nasa/casi.ntrs.nasa.gov/20110015 650.pdf (date of access April 22, 2019).

57. Anderson J. L. NASA's Nanosail-D 'Sails' Home - Mission Complete. NASA.gov. URL : https://www.nasa .gov/mission_pages/smallsats/11-148.html (date of access April 22, 2019).

58. Wolanski P. PW-SAT first polish satellite. S\&T Subcommittee of COPUOS. 2012. URL: http://www.oosa.unvienna.org/pdf/pres/stsc2012/tech-44E.pdf (date of access April 22, 2019).

59. Williams K. NASA's Exo-Brake 'Parachute' to Enable Safe Return for Small Spacecraf. NASA.gov. 2017. URL: https://www.nasa.gov/directorates/spacetech/small_spacecraft /feature/exo-brake_parachute (date of access April 22, 2019).

60. Hoyt R., Forward R. Performance of the Terminator Tether for Autonomous Deorbit of LEO Spacecraft. AIAA-99-2839 35-th Join Propulsion Conference \& Exhibit. 20 - 24 June. Los Angeles. 1999. Pp. 1-10.

61. Hoyt R., Forward R. Application of the terminator tether ${ }^{\mathrm{TM}}$ electrodynamic drag technology to the deorbit of constellation spacecraft. American Institute of Aeronautics and Astronautics Inc. 1998. Pp. 1-19. URL: http://www.tethers.com/papers/TTPaper.pdf (date of access April 22, 2019).

62. Carmen Pardini, Toshiya Hanada, Paula H. Krisko. Benefits and risks of using electrodynamic tethers to deorbit spacecraft. IAC-06-B6.2.10. URL: https://www.iadc-online.org/Documents/IADC-06-08.pdf (date of access April 22, 2019).

63. Mishchenko $O$. V. On the determination of the tether length for an experimental electrodynamic system (in Russian). Teh. Meh. 2017. No. 4. Pp. 55-63.

64. Pirozhenko A.V., Mischenko A.V. Small experimental electrodynamic space tether system. electrical model (in Russian). Space Sci.\&Technol. 2018. V. 24 No.3 Pp. 3-9. doi: 10.15407/knit2018.03.003

65. Kawashima R., Bak J., Matsuzawa S., Inamori T. Particle Simulation of Plasma Drag Force Generation in the Magnetic Plasma Deorbit. Tokyo University. 2018. URL: www.al.t.utokyo.ac.jp/members/junhwib/docs/2018K awashima_JSR.pdf (date of access 22.04.2019). 
66. Shuvalov V.A., Kuchugurnyi Yu. P. Experimental substantiation of effectiveness of conception of artificial mini-magnetosphere as a means of spacecraft motion controlling in the Earth ionosphere (in Russian). Space Sci.\&Technol. 2018, V. 24 No.2 Pp. 43-46. doi: 10.15407/knit2018.02.043

67. Shuvalov V. A., Gorev N. B., Tokmak N. A., Pis'menny N. I., Kochubei G. S. Control of the drag on a spacecraft in the earth's ionosphere using the spacecraft's magnetic field. Acta Astronautica. 2018. V. 151. Pp. 717 -725. doi: 10.1016/j.actaastro.2018.06.038

68. Shuvalov V. A., Tokmak N.A., Pis'mennyi N.I., Kochubei G.S. Dynamic interaction of a magnetized solid body with a rarefied plasma flow. Journal of Applied Mechanics and Technical Physics. 2016. V.57. No.1. Pp. 145152. doi: 10.1134/S0021894416010168

69. Ukrainian Patent for Utility Model No. 125265, IPC B64G 1/00, B64G 1/10, B64G 1/24. Space object orbit transfer method (in Ukrainian). Shuvalov V. O., Dehtiarenko P. H., Symanov V. H., Khorolskyi P. H., Loboda P. I. u2017 09603 ; filed October 2, 2017 ; published May 10, 2018.

70. Lapkhanov E. ., Paliy A. S. Current problems involving the deployment and deorbit of nano- and picosatellite constellations (in Russian). Aviatsionno-Kosmicheskaya Tekhnika i Tekhnologiya. 2018. V. 148 No. 4. Pp. 20-35. doi: 10.32620/aktt.2018.4.03

71. Lapkhanov E. O., Paliy $O$. S. Analysis of the possibility to use a propulsion system with permanent magnets for spacecraft in a near-Earth orbit (in Ukrainian). System Technologies. 2018. No. 4. Pp. 24-35.

72. Trofimov S. P. Removal of small spacecraft from the upper segment of low orbits using a sail to increase the force of light pressure (in Russian). Preprinty IPM im. M.V.Keldysha. 2015. No. 32. 32 p. URL: http://library.keldysh.ru/preprint.asp?id=2015-32 (date of access April 22, 2019).

73. Heaton A. F., Faller B. F., Katan C. K. NanoSail-D orbital and attitude dynamics. advances in solar sailing, M. Macdonald (Ed.). Springer-Verlag Berlin Heidelberg. 2014. Pp. 95 - 113.

74. Mori O., Sawada H., Funase R., Endo T., Morimoto M., Yamamoto T., Tsuda Y., Kawakatsu Y., Kawaguchi J. Development of first solar power sail demonstrator - Ikaros. JAXA Space Exploration Center. Japan. URL: http://issfd.org/ISSFD_2009/AOCSI/Mori.pdf (date of access April 22, 2019).

75. Herbeck L., Sickinger C., Eiden M., Leipold M. Solar sail hardware developments. European Conference on Spacecraft Structures: Materials and Mechanical Testing. Toulouse. 2002. Pp. 1-10.

76. Leipold M., Garner C. E., Freeland R., Hermann A., Noca M., Pagel G., Seboldt W., Sprague G., Unckenbold W. Odissee - a proposal for demonstration of a solar sail in earth orbit. Acta Astronautica. 1999. V. 45. No. 4. Pp. 557-566. doi: 10.1016/S0094-5765(99)00176-9

77. Pfisterer M., Schillo K., Valle C.,. Lin K.-C, Ham C. The Development of a Propellantless Space Debris Mitigation Drag Sail for LEO Satellites. Space Mission Analysis and Design. 2011. URL: http://www.iiis.org/Chan.pdf (date of access April 22, 2019).

78. Alpatov A. P., Svorobin D. S., Skoryk O. D. System for contactless removal of space debris from near-earth orbits using aerodynamic compensator (in Ukrainian). Teh. Meh. 2016. No. 3. Pp. 51-56.

79. Svorobin D. S., Fokov A. A., Khoroshylov S. V. Feasibility analysis of aerodynamic compensator application in noncontact space debris removal (in Russian). Aviatsionno-Kosmicheskaya Tekhnika i Tekhnologiya. 2018. No. 6. Pp. 4-11. doi: 10.32620/aktt.2018.6.01

80. Shuvalov, V. O., Palij, O. S., Lapkhanov, E. O. Method of clearing of near-Earth space from objects of space debris by removing them from orbit with the help of own magnetic field. (in Ukrainian) An application for a patent of Ukraine for invention, no. a201801742, 2018. filed March 10, 2018. 